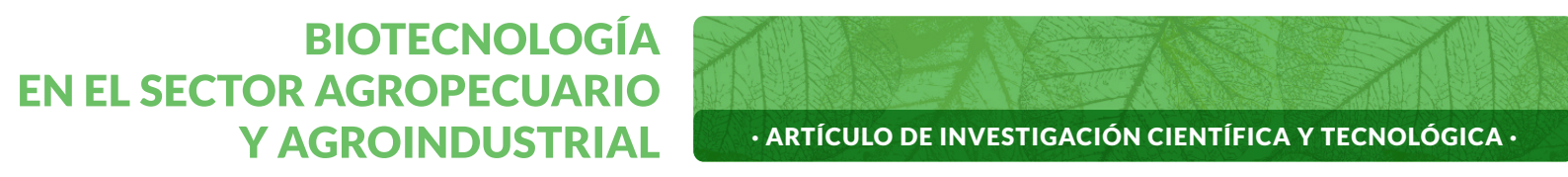

Vol. 20 No 1· Enero-Junio 2022 · ISSN-1692-3561· ISSN-e 1909-9959· DOI: https://doi.org/10.18684/bsaa.v.n.2022.1839

\title{
Digestibility, rumen kinetics, and blood metabolites in lambs fed Samanea saman and Cordia dentata*
}

\section{Digestibilidad, cinética ruminal y metabolitos sanguíneos en corderos alimentados con Samanea saman y Cordia dentata}

GUTIERREZ-OVIEDO, FABIAN¹; PARDO-GUZMÁN, JAIRO²; CASTAÑEDA-SERRANO, ROMÁN

Historial del artículo

Recibido para evaluación: 1 marzo 2021.

Aprobado para publicación: 1 septiembre 2021.

* Título del proyecto de origen: "Innovación y gestión técnico científica para el desarrollo de la cadena ovino caprina del departamento del Tolima“. Financiación: Sistema General de Regalías SGR Departamento del Tolima, Colombia. Culminación: 01 de Junio de 2020.

1 Universidad del Tolima, Facultad de Medicina Veterinaria y Zootecnia, Grupo de Investigación en Sistemas Agroforestales Pecuarios. Médico Veterinario y Zootecnista. Ibagué, Colombia. https://orcid.org/0000-0001-7585-0606

2 Universidad del Tolima, Facultad de Medicina Veterinaria y Zootecnia, Grupo de Investigación en Sistemas Agroforestales Pecuarios. Médico Veterinario y Zootecnista. Ibagué, Colombia. http://orcid.org/0000-0002-4746-5978

3 Universidad del Tolima, Facultad de Medicina Veterinaria y Zootecnia, Grupo de Investigación en Sistemas Agroforestales Pecuarios. Doctor en Zootecnia. Ibagué, Colombia. https://orcid.org/0000-0002-6935-3918

Corresponding author: rcastaneda@ut.edu.co

Cómo citar este artículo: GUTIERREZ-OVIEDO, FABIAN; PARDO-GUZMÁN, JAIRO; CASTAÑEDA-SERRANO, ROMÁN. Digestibility, rumen kinetics, and blood metabolites in lambs fed Samanea saman and Cordia dentata. Revista Biotecnología en el Sector Agropecuario y Agroindustrial, v. 20, n. 1, 2022, p. 113-123. Doi: https://doi.org/10.18684/bsaa.v.n.2022.1839 


\section{ABSTRACT}

Colombian sheep production is carried out in extensive pastures with a low percentage of protein and high fiber levels that lead to low weight gains. The aim of this study was to evaluate intake, digestibility, rumen kinetics, and blood metabolites in hair lambs fed Samanea saman and Cordia dentata. Twelve hair lambs were distributed in an experimental $4 \times 4$ Latin square design, with four treatments and four experimental periods. Treatments were T1:100 \% Dichanthium spp hay, T2: 80\% Dichanthium spp hay, 20\% S. saman, T3:80\% Dichanthium spp hay, 20\% C. dentata, T4:80\% Dichanthium spp hay, 10\% S. saman, and 10\% C. dentata. The highest nutrients intakes were obtained with diets containing tree foliage compared with the T1 diet ( $p<0,05)$. In vivo and In vitro digestibility of DM, OM and, NDF of tree leaves diets showed higher values than the T1 diet $(p<0,05)$. Digestible and metabolizable energy were similar between tree leaves diets $(p<0,05)$. Blood urea nitrogen values were superior for animals fed the T2 diet $(p<0,05)$. Degradability values at 96 hours were higher for the T2 diet $(p<0,05)$. Potential degradability was superior for the T3 diet. The results of this study demonstrate that $S$. saman and $C$. dentata leaves improve nutrients intake and digestibility. Therefore, they can be an alternative for sheep in the tropical dry forest.

\section{RESUMEN}

La producción ovina colombiana se realiza en pastos extensivos con bajo porcentaje de proteína y altos niveles de fibra que conducen a bajas ganancias de peso. El objetivo de esta investigación fue evaluar el consumo, digestibilidad, cinética ruminal y metabolitos sanguíneos en corderos de pelo alimentados con Samanea saman y Cordia dentata. Se distribuyeron doce corderos de pelo en un diseño experimental cuadrado latino $4 \times 4$, con cuatro tratamientos y cuatro períodos experimentales. Los tratamientos fueron T1: $100 \%$ Dichanthium spp, T2: 80 \% Dichanthium spp, 20 \% de S. saman, T3: $80 \%$ de Dichanthium spp, 20 $\%$ de C. dentata, T4: $80 \%$ de Dichanthium spp, $10 \%$ de S. saman y $10 \%$ C. dentata. Las mayores ingestas de nutrientes se obtuvieron con dietas que contenían follaje arbóreo $(p<0,05)$. La digestibilidad in vivo e in vitro de MS, MO y FDN de las dietas con follaje arbóreo mostro valores más altos que la dieta $T 1(p<0,05)$. La energía digestible y metabolizable fue similar entre las dietas con follaje arbóreo $(p<0,05)$. Los valores de nitrógeno ureico en sangre fueron superiores para los animales alimentados con dieta T2 $(p<0,05)$. Los valores de degradabilidad a las 96 horas fueron mayores para la dieta T2 $(p<0,05)$. La degradabilidad potencial fue superior para la dieta T3. Los resultados de este estudio demuestran que el follaje de S. saman y C. dentata mejoran el consumo y la digestibilidad.

\section{INTRODUCTION}

Ruminants play an important role in food security in developing countries because they can convert fibrous foods such as grass and agro-industrial residues into products of high biological value like meat and milk (Guyader et al., 2016). In these regions, most of the sheep farms present a low

\section{KEYWORDS:}

Energy; Hair sheep; Nutrition; Protein; Ruminants; Silvopastoral systems; Small Ruminants; Supplementation; Tropical dry forest; Tropical tree fodder.

\section{PALABRAS CLAVES:}

Bosque seco tropical; Energía; Forraje de árboles tropicales; Nutrición; Ovinos de pelo; Pequeños rumiantes; Proteína; Rumiantes; Sistemas silvopastoriles; Suplementación. 
level of adoption of technologies, limitations of commercialization, and extensive grazing in pastures with low protein content and high fiber, thus leading to low body weight gain and low income (Vega-Pérez et al., 2017) To solve this, the major trend in ruminant production has been the increase of grain feeding (Dumont et al., 2018). However, these feed sources have disadvantages for small farmers, such as the high price, fluctuations in international markets, and the demand for cereals for biodiesel production (Thompson et al., 2019). Hence, many studies have proved that using tropical trees and shrub leaves in ruminants diets can improve performance and decrease methane production (Vandermeulen et al., 2018) Latin American Tropical dry forests present a high degree of diversity and endemism (Banda et al., 2016). Many of these plants can be used for feeding because they have protein levels greater than $15 \%$ and fiber levels less than $60 \%$ (Perez et al., 2013). Previous research demonstrated that Samanea saman and Cordia dentata are suitable for ruminant feeding. Since they have high protein levels and lower fiber values (Delgado et al., 2014) than Angleton grass (Dichanthium spp.), a typical grass from the tropical dry forest, characterized for its low protein, high fiber, and low digestibility (Mantilla et al., 2010).

However, there is a lack of information about the effect of including S. saman and C. dentata leaves on intake, digestibility, ruminal kinetics, and nutritional value in ruminant diets. Thus, the aim of this research was to evaluate the effect of partial replacement of Angleton (Dichanthium spp) hay by S. saman and C. dentata leaves on feed intake, in vivo and in vitro digestibility, ruminal kinetics, and blood metabolites in hair lambs.

\section{METHOD}

\section{Localization}

This experiment was conducted from June to September 2017 at the experimental farm "Las Brisas" of the University of Tolima, in the city of Ibague, department of Tolima, Colombia, located at $4^{\circ} 25^{\prime} 38.4^{\prime \prime} \mathrm{N}+75^{\circ} 13^{\prime} 40.8^{\prime \prime}$ W, 1285 masl with annual precipitation between 1.500 and $2.000 \mathrm{~mm}$ and an average temperature of $23,1^{\circ} \mathrm{C}$.

\section{Experimental diets and treatments}

The Dichanthium spp was collected at the "Centro Universitario Regional del Norte" of the University of Tolima, Armero, Tolima, Colombia. The hay was chopped into one to three $\mathrm{cm}$ of size for ease of feeding. The $S$. saman and C. dentata leaves were collected at intervals of 45 days at "Centro de Investigación NATAIMA",EI Espinal, Colombia.

The experimental diets consisted of Dichanthium spp hay with partial replacement by S. saman and C. dentata leaves (Table 1).

T1: $100 \%$ Dichanthium spp;

T2: 80 \% Dichanthium spp hay, 20 \% S. saman;

T3: 80 \% Dichanthium spp, $20 \%$ C. dentata;

T4: 80 \% Dichanthium spp, $10 \%$ S. saman, $10 \%$ C. dentata 
Table 1. Bromatological composition of the ingredients and diets for hair lambs.

\begin{tabular}{|c|c|c|c|c|c|c|c|}
\hline \multirow{2}{*}{ Nutrients } & \multicolumn{3}{|c|}{ Feed ingredients } & \multicolumn{4}{c|}{ Experimental diets $^{\text {a }}$} \\
\cline { 2 - 8 } & Dichanthium spp & S. saman & C. dentata & T1 & T2 & T3 & T4 \\
\hline DM & 89,7 & 91,6 & 90,2 & 89,7 & 90,0 & 89,8 & 89,9 \\
\hline OM & 92,8 & 94,8 & 81,9 & 92,8 & 93,2 & 90,6 & 91,9 \\
\hline CP & 3,4 & 20,4 & 13,5 & 3,4 & 6,8 & 5,4 & 6,1 \\
\hline NDF & 77,2 & 52,1 & 58,4 & 77,2 & 72,1 & 73,4 & 72,8 \\
\hline ADF & 39,7 & 31,7 & 35,1 & 39,7 & 38,1 & 38,8 & 38,4 \\
\hline Lignin & 12,3 & 11,2 & 16,9 & 12,3 & 12,1 & 13,2 & 12,6 \\
\hline EE & 1,1 & 2,3 & 1,5 & 1,1 & 1,4 & 1,2 & 1,3 \\
\hline Ash & 7,1 & 5,1 & 18,1 & 7,1 & 6,7 & 9,3 & 8,0 \\
\hline TC & 88,4 & 72,2 & 67 & 88,4 & 85,1 & 84,1 & 84,6 \\
\hline CNF & 11,2 & 20,1 & 8,6 & 11,2 & 13 & 10,7 & 11,8 \\
\hline
\end{tabular}

a T1: Dichanthium spp; T2: 80 \% Dichanthium spp, $20 \%$ S. saman; T3: 80 \% Dichanthium spp, 20 \% C. dentata; T4: 80 \% Dichanthium spp, $10 \%$ S. saman, C. dentata.

\section{Animals and experimental design}

This study was carried out following the guidelines of the University of Tolima (agreement of the academic council number 0171 of October 29, 2008) and act number 02 of 2017 of the committee of bioethics.

Twelve castrated Colombian hair lambs $(20,15 \pm 1,67 \mathrm{~kg}$ and an average age of six months) were randomly distributed and allocated to one of four dietary treatments. Each group received one of the diets under $4 \times 4$ Latin Square experimental design with four treatments, four experimental periods, and three animals for each treatment.

\section{Sample collection}

In vivo digestibility was determined by the total collection of feces. Each experimental period was divided into two: 12 days of diet adaptation and five days for data and sample collection. During the adaptation period, the lambs were located in pens for each treatment and fed at $4 \%$ of live body weight. In the collection period, the lambs were housed in metabolic cages equipped with feeders, waterers, and collectors of feces and urine. The diet was adjusted to obtain 5-10\% orts. Feces and orts were collected every morning before feeding and weighed, and samples were taken and frozen for further analysis.

Samples of feeds, orts, and feces were pre-dried for 72 hours in an air circulation stove at $55^{\circ} \mathrm{C}$ and ground in Willey type mills ( $2 \mathrm{~mm}$ mesh) and analyzed for Dry Matter (DM), Crude Protein (CP), Ether Extract (EE), (AOAC, 2009); Neutral Detergent Fiber (NDF), Acid Detergent Fiber (ADF), and lignin content (Van Soest et al., 1991), Total Carbohydrates (TC). Non-Fiber Carbohydrates (NFC) were calculated as follows (Equation 1) (Sniffen et al., 1992)

$$
N F C=100-(C P+N D F+E E+M M)
$$

Blood samples were collected per animal on the last day of each experimental period. They were analyzed for Plasma glucose, NEFA, and BHBA concentrations using commercial Biosystems ${ }^{\circledR}$ (glucose and BUN) and Randox ${ }^{\circledR}$ (?-hydroxybutyrate) kits and Biosystems $A 15 \otimes$ automatic blood chemistry system at the Laboratory of Veterinary Diagnostics at the University of Tolima-LADIVE. 


\section{Intake and apparent digestibility evaluations}

$\mathrm{DM}, \mathrm{OM}, \mathrm{CP}, \mathrm{NDF}, \mathrm{ADF}, \mathrm{EE}, \mathrm{TC}, \mathrm{NFC}$, intake, and TDN of each treatment were calculated by the difference between the total of each nutrient contained in the feed offered to the lambs and the amount in the orts, expressed in grams per animal per day $\left(\mathrm{g} \mathrm{d}^{-1}\right)$, Apparent digestibility (AD) of DM, OM, CP, NDF, EE, TC, and NFC was obtained using the equation as follows (Equation 2). where: $\mathrm{Nf}=$ nutrient in feed $(\mathrm{g}) ; \mathrm{No}=$ nutrient in orts (g); and Nfc = nutrient in feces (g).

$$
\mathrm{AD}=((\mathrm{Nf}-\mathrm{No}-\mathrm{Nfc}) /(\mathrm{Nf}-\mathrm{No})) \times 100
$$

TDN was calculated as follows (Equation 3) (Weiss, 1993) where subscript $d$ means digestible.

$$
T D N=C P d+N F C d+a N D F d+E E d \times 2,25
$$

The DE was estimated at 4,4 Mcal $/ \mathrm{kg}$ of TDN, and the DE was converted to ME at an $82 \%$ efficiency rate (National Research Council-NRC, 2007).

\section{In vitro digestibility and ruminal degradability}

In vitro DM digestibility (IVDMD) was determined based on the technique proposed by Tilley and Terry (1963), adapted to the DAISY $I^{\circledR}{ }^{\circledR}$-ANKOM ${ }^{\circledR}$ artificial rumen. Ruminal fluid was obtained from a rumen-cannulated Gyrolando steer maintained in a pen of Dichanthium spp grass with water ad libitum. For each feed sample (preground to $1 \mathrm{~mm}$ ), 0,5 g were placed into $F 57 \mathrm{ANKOM} \otimes$ filter bags. Then they were then distributed in four glass containers with buffered solutions $A$ and $B$ and ruminal inoculum. Subsequently, they were introduced into the DAISY $1{ }^{\otimes}$ incubator for 48 hours at a constant temperature of $39^{\circ} \mathrm{C}$. At the end of this period, $40 \mathrm{~mL}$ of $6 \mathrm{~N}$ $\mathrm{HCl}$ and $8 \mathrm{~g}$ of pepsin were added (EC 3.4.23.1 Sigma ${ }^{\circledR}$ ). The samples were left in an incubator for an additional 24 hours. Subsequently, the bags were dried at $105^{\circ} \mathrm{C}$ for eight hours; DIVMS was calculated as the difference between the incubated feed and the residue after incubation.

Degradation kinetics of DM was determined in parallel within in vitro dry matter digestibility using the DAISY

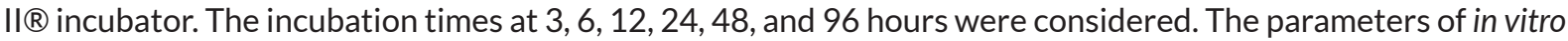
rumen degradation of DM were calculated as follows (Equation 4) (Orskov and McDonald, 1979), where, $P$ is the amount degraded at time t, "a" is the rapidly soluble fraction, "b" is the potentially degradable fraction, "c" is the rate of degradation of fraction $b$.

$$
P=a+b\left(e^{-c t}\right)
$$

Potential degradability (PD) was calculated using the following equation (Equation 5) where $a$ and $b$ represent the soluble and degradable fractions, respectively.

$$
\mathrm{PD}=\mathrm{a}+\mathrm{b}
$$

The effective degradability (ED) of the DM was calculated using the following equation (Equation 6) where $k$ is the velocity of the passage of particles in the rumen, estimated for each diet, considering the passage rates of 2 , 5 , and $8 \%$ /hour, values that can be attributed to low, medium, and high consumption levels, respectively. 


$$
E D=a+(b \times c / c+k)
$$

\section{Statistical analysis}

Nutrients intake, digestibility, and blood metabolites data were statistically using the general linear model procedure of SAS software (Statistical Analysis System, version 9,1). The treatment, period, and animal and their respective interactions as fixed effects. When the analysis of variance indicated the existence of differences between treatments, the respective means were compared using the Tukey test with significance declared at $\mathrm{p}<0,05$. Analysis of variance was carried out for in vitro digestibility, in vitro degradability and degradability kinetic parameters were compared using the Tukey test with significance declared at $p<0,05$.

\section{RESULTS}

\section{Intake}

DM, OM, NDF intake were higher in the diets containing tree leaves $(p<0,01)$. Furthermore, NDF intake containing T4 was superior to the other diets $(p<0,01)$. The CP intake was lower in lambs fed with the T1 diet, while the lambs fed diets with T2 and T4 showed higher values $(p<0,01)$ (Table 2). The dry matter intake increased between 45 to $59 \%$ in lambs fed with S. saman and C. dentata. The increase of their intake contributes to improving OM, CP, NDF, EE, TC, NFC, and TDN consumption. These findings corroborate the results of Castañeda-Serrano et al. (2018) who reported a similar intake in lambs fed with $25 \%$ of G. ulmifolia, G. sepium, or T. diversifolia leaves with a basal diet of Dichanthium spp hay and rice bran. In our study, the lowest DM intake was obtained with the $100 \%$ Dichanthium spp diet, which contains 5 to $7 \%$ more fiber than other diets. Less fiber in diets with tree leaves might have resulted in less time in chewing and ruminal filling and a higher ruminal outflow that might have caused a higher intake (Niderkorn et al., 2019) Protein intake is the main factor in daily weight gain. We found protein intake with tree leaves increased between 44 to $59 \%$ in the lambs fed with diets with tree leaves (Costa-Germano et al., 2018) Similarly, Marsetyo et al. (2020) reported that lambs fed basal diets of Mulato grass with supplementation of Centrosema pascuorum, Dolichos lablab, or Clitoria ternatea showed higher nutrients intake compared with the control diet but not showed differences between them. This occurred because lambs fed ad libitum can choose feeds, or parts of them, which are of good nutritional quality (Moyo et al., 2019) Otherwise, the results of this study suggest high acceptability of S. saman and C. dentata by ruminants in accordance with Pérez-Almario et al. (2013) who reported high acceptability of S. saman and C. dentata by dairy cows.

Table 2. Nutrients intake in hair lambs fed with Dichanthium spp; S. saman and C. dentata.

\begin{tabular}{|c|c|c|c|c|c|c|}
\hline \multirow{2}{*}{$\begin{array}{l}\text { Intake (g/ } \\
\text { day) }\end{array}$} & \multicolumn{4}{|c|}{ Experimental diets } & \multirow{2}{*}{ SEM } & \multirow{2}{*}{$\mathbf{P}$} \\
\hline & T1 & T2 & T3 & T4 & & \\
\hline DM & $437,4 a$ & $635,2 b$ & $633,8 b$ & $698,7 b$ & 17,7 & $<0,01$ \\
\hline OM & $406,3 a$ & $596,9 b$ & $574,8 b$ & $643,3 b$ & 16,28 & $<0,01$ \\
\hline $\mathrm{CP}$ & $13,0 a$ & $51,5 c$ & $34,5 b$ & $45,8 c$ & 2,27 & $<0,01$ \\
\hline NDF & $316,3 a$ & $436,2 b$ & $451,8 b c$ & $502,5 c$ & 12,98 & $<0,01$ \\
\hline $\mathrm{EE}$ & $6,3 a$ & $8,7 \mathrm{~b}$ & $8,2 b$ & $8,7 \mathrm{~b}$ & 0,22 & $<0,01$ \\
\hline TC & $375,9 a$ & $535,3 b$ & $531,5 b$ & $587,5 b$ & 14,6 & $<0,01$ \\
\hline NFC & $42,7 a$ & $80,4 c$ & $63,2 b$ & $67,5 b$ & 2,54 & $<0,01$ \\
\hline TDN & $149,0 a$ & $378,9 b$ & $343,6 b$ & $417,3 b$ & 2,17 & $<0,01$ \\
\hline
\end{tabular}




\section{Digestibility}

DM, MO, NDF, TC digestibility and, IVDMD were higher for diets with tree leaves than the T1 diet, but they did not show differences between them $(p<0,01)$. CP digestibility was highest for the T2 diet, followed by T3, T4, and T1 diet $(p<0,01)$. EE and NFC digestibility did not show a difference between diets $(p>0,05)$. The TDN values for diets with tree leaves were higher than the T1 diet $(p<0,01)$ (Table 3$)$. The highest digestibility of DM, OM, CP, NDF, and TC for the treatments with tree leaves, is consistent with the results of Sio et al. (2018). They evaluated the digestibility of the diets with three levels of Paraserianthes falcataria leaves (10, 15, and $20 \%$ ) in a grass basal diet and found that from $10 \%$ of inclusion, it is possible to improve the digestibility of nutrients due to the rapid growth of the microbial population of the rumen because S. saman and C. dentata have high levels of protein and medium of low levels of NDF (Gebregiorgis et al., 2012).

Table 3. Nutrients digestibility (\%) and energy values in hair lambs fed with Dichanthium spp, S. saman, and C. dentata.

\begin{tabular}{|c|c|c|c|c|c|c|}
\hline \multirow{2}{*}{ Item } & \multicolumn{4}{|c|}{ Experimental diets } & \multirow{2}{*}{ SEM } & \multirow{2}{*}{$\mathbf{P}$} \\
\hline & T1 & T2 & T3 & T4 & & \\
\hline DM & $37,1 a$ & $61,4 \mathrm{~b}$ & $55,3 b$ & $63,4 b$ & 2,1 & $<0,01$ \\
\hline OM & $40,3 a$ & $64,2 b$ & $57,4 b$ & $65,2 b$ & 2,0 & $<0,01$ \\
\hline $\mathrm{CP}$ & $20,2 a$ & $64,5 d$ & $36,2 b$ & $50,1 c$ & 2,8 & $<0,01$ \\
\hline NDF & $37,3 a$ & $63,8 b$ & $60,7 b$ & $67,0 \mathrm{~b}$ & 2,4 & $<0,01$ \\
\hline $\mathrm{EE}$ & 50,0 & 59,8 & 55,8 & 50,5 & 2,4 & 0,44 \\
\hline $\mathrm{TC}$ & $37,0 a$ & $64,2 b$ & $58,9 b$ & $66,5 b$ & 2,3 & $<0,01$ \\
\hline NFC & 35,5 & 59,3 & 30,1 & 50,6 & 6,5 & 0,37 \\
\hline TND & $32,9 a$ & $59,1 b$ & $52,9 b$ & $59,4 b$ & 2,1 & $<0,01$ \\
\hline IVDMD & $44,9 a$ & $55,5 c$ & $51,4 b$ & $54,1 \mathrm{ab}$ & 0,9 & $<0,01$ \\
\hline $\mathrm{DE}$ (Mcal/Kg DM) & $1,4 a$ & $2,6 b$ & $2,32 b$ & $2,6 b$ & 0,95 & $<0,01$ \\
\hline $\mathrm{ME}^{(\mathrm{Mca} / \mathrm{Kg} \mathrm{DM})}$ & $1,1 a$ & $2,1 b$ & $1,9 b$ & $2,1 b$ & 0,07 & $<0,01$ \\
\hline
\end{tabular}

\section{Blood metabolites}

Glucose values showed no differences between treatments $(p>0,05)$. $\beta H B$ showed a similar pattern $(p>0,05)$. Furthermore, the BUN of lambs fed the T2 diet showed higher values $(p<0,01)$. (Table 4). The blood urea nitrogen (BUN) values were lower than those established for sheep (Carlos-Leite et al., 2015). Low levels of this metabolite may be due to deficient protein or energy in the diet (De Oliveira et al., 2016). However, the highest levels of BUN in T2 treatment could indicate a better contribution of nitrogen to microbial protein production. Glucose values are closely correlated with dry matter and energy intake. However, in our trial, we did not observe differences between the treatments even though we observed differences for feed consumption, and the energy values were lower for the T1 diet. Regarding the $\beta \mathrm{HB}$ concentrations, these did not differ between treatments, and their values were below the proposed in sheep (Catunda-Vasconcelos et al., 2013) (5,33 to 6,17 $\mathrm{mg} / \mathrm{dL}$ ). According to these results, it can be inferred that the lambs were not in a negative energy balance. 
Table 4. Blood metabolites in lambs fed with Dichanthium spp, S. saman, and C. dentata.

\begin{tabular}{|c|c|c|c|c|c|c|}
\hline \multirow{2}{*}{ Item } & \multicolumn{4}{|c|}{ Experimental diets } & \multirow[t]{2}{*}{ SEM } & \multirow{2}{*}{$\mathbf{P}$} \\
\hline & T1 & T2 & T3 & T4 & & \\
\hline Glucose, $\mathrm{mg} \mathrm{dL}^{-1}$ & 64,5 & 67,2 & 63,3 & 66,0 & 1,3 & 0,77 \\
\hline BUN, $\mathrm{mg} \mathrm{dL}^{-1}$ & $3,8 a$ & $7,5 b$ & $2,6 a$ & $3,1 a$ & 0,39 & $<0,01$ \\
\hline$\beta \mathrm{HB}, \mathrm{mg} \mathrm{dL}^{-1}$ & 3,3 & 4,1 & 3,7 & 4,1 & 0,17 & 0,27 \\
\hline
\end{tabular}

\section{Ruminal Degradability and degradability kinetics}

At $96 \mathrm{~h}$ the T2 showed the highest degradability among the other diets. On the other hand, the T3 and T4 diets presented higher values than the T1 diet (Table 5). Regarding effective degradability, the highest values were observed in the T2 diet in the three levels of passage rate. The "a" and "fraction in the T3 diet was superior to the other diets. However, its "c" fraction was lower. The potential degradability was higher for the T3 diets (Table 6). The "a" fraction shown in tree leaves diets might be attributed to higher CP levels in S. saman and C. dentata, leading to a high amount of nitrogen available in the rumen used to produce microbial protein, the principal source of proteins for ruminants (De Oliveira et al., 2014). Patra and Yu $(2014,2015)$ showed that saponins found in S. saman (Anantasook et al., 2015) and nitrates found in C. dentata (Garcia et al., 2009), could inhibit methane production, allowing the growth of cellulolytic bacteria and increases the feed degradability and production of volatile fatty acids. Otherwise, in this study, the T4 diet shows the lower "b" fraction. To the knowledge of the authors, there are no studies that evaluated or explained the in vivo interaction between saponins and nitrates.

Table 5. In vitro degradability by hours of dry matter in diets for hair lambs using Dichanthium spp, S. saman, and C. dentata.

\begin{tabular}{|c|c|c|c|c|c|c|}
\hline \multirow{2}{*}{ Degradability } & \multicolumn{4}{|c|}{ Treatments } & \multirow[t]{2}{*}{ SEM } & \multirow[t]{2}{*}{$\mathbf{P}$} \\
\hline & T1 & $\mathrm{T} 2$ & T3 & $\mathrm{T} 4$ & & \\
\hline 3 & $12,1 \mathrm{a}$ & $16,9 b$ & $16,2 b$ & $14,9 a b$ & 0,63 & $<0,01$ \\
\hline 6 & $14,7 a$ & $18,9 b$ & $19,8 b$ & $17,8 a b$ & 0,62 & $<0,01$ \\
\hline 12 & 21,5 & 24,1 & 22,3 & 21,6 & 0,50 & 0,22 \\
\hline 24 & $29,0 \mathrm{ab}$ & $35,1 \mathrm{c}$ & $27,4 a$ & $30,7 a b$ & 0,91 & 0,02 \\
\hline 48 & $42,7 a$ & $48,9 b$ & $40,1 a$ & $43,1 a$ & 1,07 & 0,03 \\
\hline 96 & $51,3 a$ & $60,7 c$ & $53,9 b$ & $54,6 b$ & 1,06 & $<0,01$ \\
\hline
\end{tabular}

T1: Dichanthium spp; T2: 80 \% Dichanthium spp, $20 \%$ S. saman; T3: 80 \% Dichanthium spp, 20 \% C. dentata; T4: $80 \%$ Dichanthium spp, $10 \%$ S. saman, C. dentata. Means with a different letter in a column are statistically different (Tukey: $p<0,05)$. SEM: Standard error of the mean.

Table 6. Degradability kinetics of diets for hair lambs using Dichanthium spp, S. saman, and C. dentata.

\begin{tabular}{|c|c|c|c|c|c|c|c|}
\hline & \multicolumn{7}{|c|}{ Parameters } \\
\hline Treatments & $\begin{array}{c}\text { A } \\
(\%)\end{array}$ & $\begin{array}{c}\text { B } \\
(\%)\end{array}$ & $\begin{array}{c}\text { C } \\
(\% / h)\end{array}$ & PD (\%) & $\begin{array}{c}\text { ED } \\
(\mathbf{K}=0,02)\end{array}$ & $\begin{array}{c}\text { ED } \\
(\mathrm{K}=0,05)\end{array}$ & $\begin{array}{c}\text { ED } \\
(\mathrm{K}=0,08)\end{array}$ \\
\hline T1 & $8,36 \mathrm{a}$ & $47,2 \mathrm{a}$ & $0,025 \mathrm{c}$ & $55,6 \mathrm{a}$ & $31,1 \mathrm{a}$ & $24,2 \mathrm{a}$ & $19,8 \mathrm{a}$ \\
\hline T2 & $12,5 \mathrm{ab}$ & $55,3 \mathrm{~b}$ & $0,021 \mathrm{~b}$ & $67,8 \mathrm{c}$ & $37,2 \mathrm{c}$ & $29,1 \mathrm{c}$ & $24,3 \mathrm{~d}$ \\
\hline T3 & $14,9 \mathrm{c}$ & $61,5 \mathrm{c}$ & $0,010 \mathrm{a}$ & $76,5 \mathrm{~d}$ & $33,0 \mathrm{~b}$ & $25,5 \mathrm{~b}$ & $22,1 \mathrm{c}$ \\
\hline T4 & $11,8 \mathrm{ab}$ & $50,6 \mathrm{a}$ & $0,019 \mathrm{~b}$ & $62,52 \mathrm{~b}$ & $33,3 \mathrm{~b}$ & $25,9 \mathrm{~b}$ & $21,8 \mathrm{~b}$ \\
\hline P & $<0,01$ & 0,03 & $<0,01$ & $<0,04$ & $<0,01$ & 0,03 & $<0,01$ \\
\hline
\end{tabular}




\section{CONCLUSIONS}

Intake, digestibility, and degradability of the nutrients improved when S. saman and C. dentata were included in the diet. We demonstrated that their inclusion does not have harmful effects on protein and energy status. Their inclusion is a promising alternative for the supplementation of low-quality grass-fed ruminants in tropical and subtropical countries.

We suggest that this information could be used as basic data for future studies, where conventional protein feeds will be replaced by $S$. saman and C. dentata.

\section{REFERENCES}

ANANTASOOK, NIRAWAN; WANAPAT, METHA; CHERDTHONG, ANUSORN; GUNUN, PONGSATORN. Effect of tannins and saponins in Samanea saman on rumen environment, milk yield and milk composition in lactating dairy cows. Journal of Animal Physiology and Animal Nutrition, v. 99, n. 2, 2015 p. 335-344. https://doi.org/10.1111/jpn.12198

BANDA, KARINA; DELGADO-SALINAS, ALFONSO; DEXTER, KYLE G.; LINARES-PALOMINO, REYNALDO; OLIVEIRA-FILHO, ARY; PRADO, DARIÉN; PULLAN, MARTIN; QUINTANA, CATALINA; RIINA, RICARDA; RODRÍGUEZ, GINA M.; WEINTRITT, JULIA; ACEVEDO-RODRÍGUEZ, PEDRO; ADARVE, JUAN; ÁLVAREZ, ESTEBAN; ARANGUREN, ANAIRAMIZ; ARTEAGA, JULIÁN-CAMILO; AYMARD, GERARDO; CASTAÑO, ALEJANDRO; CEBALLOS-MAGO, NATALIA; COGOLLO, ÁLVARO; CUADROS, HERMES; DELGADO, FREDDY; DEVIA, WILSON; DUEÑAS, HILDA; FAJARDO, LAURIE; FERNÁNDEZ, ÁNGEL; FERNÁNDEZ, MILLER-ÁNGEL; FRANKLIN, JANET; FREID, ETHAN H.; GALETTI, LUCIANO A.; GONTO, REINA; GONZÁLEZ, ROY; GRAVESON, ROGER; HELMER, EILEEN H.; IDÁRRAGA, ÁLVARO; LÓPEZ, RENÉ; MARCANO-VEGA, HUMFREDO; MARTÍNEZ, OLGA G.; MATURO, HERNÁN M.; MCDONALD, MORAG; MCLAREN, KURT; MELO, OMAR; MIJARES, FRANCISCO; MOGNI, VIRGINIA; MOLINA, DIEGO; MORENO, NATALIA-DEL PILAR; NASSAR, JAFET M.; NEVES, DANILO M.; OAKLEY, LUIS J.; OATHAM, MICHAEL; OLVERA-LUNA, ALMA ROSA; PEZZINI, FLÁVIA F.; REYES DOMINGUEZ, ORLANDO-JOEL; ELVIRA RÍOS, MARÍA; RIVERA, ORLANDO; RODRÍGUEZ, NELLY; ROJAS, ALICIA; SÄRKINEN, TIINA; SÁNCHEZ, ROBERTO; SMITH, MELVIN; VARGAS, CARLOS; VILLANUEVA, BORIS; PENNINGTON, TOBY. Plant diversity patterns in neotropical dry forests and their conservation implications. Science, $v$. 353, n. 6306, 2016 p. 1383-1387. https://doi.org/10.1126/science.aaf5080.

CARLOS-LEITE, MARIA-MARÍLIA; CHAVES-FERREIRA, DOWGLISH; VALE, ANDRÉ M.; FAÇANHAEVANGELISTA, DÉBORA-ANDRÉA; MELO-MARTINS, MARÍLIA; SOTO-BLANCO, BENITO. Blood parameters in the morada nova sheep: Influence of age, sex and body condition score. Journal of Animal and Plant Sciences, v. 25, n. 4, 2015, p. 950-955.

CASTAÑEDA-SERRANO, ROMÁN; PIÑEROS-VARÓN, ROBERTO; VÉLEZ-GIRALDO, ALEJANDRA. Foliage of tropical arboreal species in feeding ovines (Ovis aries): Intake, digestibility and balance nitrogen. Boletín Científico. Centro de Museos. Museo de Historia Natural, v. 22, n. 1, 2018, p. 58-68.

CATUNDA-VASCONCELOS, ANA-CLAUDIA; LIMA-SILVA, ITALO-CORDEIRO; BANDEIRA-CANDIDO, GABRIEL; GADELHA-FIGUEIREDO, CARLA-RENATA; PEREIRA-SALES, ELZENIA; SALMITOVANDERLEY, CARMINDA-SANDRA; ALENCAR-DE-ARAÚJO, AIRTON; GABRIMAR-ARAÚJO, MARTINS; CAMPOS-NASCIMENTO, ANA-CLÁUDIA. Blood leptin, insulin and glucose concentrations in hair sheep raised in a tropical climate. Small Ruminant Research, v. 114, n. 2-3, 2013, p. 272-279. https://doi.org/10.1016/j.smallrumres.2013.07.008. 
COSTA-GERMANO, ROBERTO; LIMA-BATISTA, HUGO; MEDEIROS-NUNES, ARIOSVALDO; CRUZ-BELTRAO, GEORGE; PEIXOTO, MARIA; SILVA, JUSCELINO. Net protein and energy requirements for weight gain of Santa Inês and Morada Nova sheep. Livestock Science, v. 214, 2018, p. 288-292. https://doi.org/10.1016/j.livsci.2018.04.011.

DELGADO, DENIA C.; HERA, ROSARIO; CAIRO, J.; ORTA, YBETT. Samanea saman, árbol multipropósito con potencialidades como alimento alternativo para animales de interés productivo. Revista Cubana de Ciencia Agrícola, v. 48, n. 3, 2014, p. 205-212

DE OLIVEIRA-REUTER, EUCLIDES; PINTO-MONÇÃO, FLÁVIO; ARAÚJO-GABRIEL, ANDRÉA-MARI; BUSCHINELLI-DE-GÓES, RAFAEL; LEMPP, BEATRIZ; VALENZUELA-MOURA, LAIS. Ruminal degradability of neutral detergent fiber of Cynodon spp. grasses at four regrowth ages. Acta Scientiarum. Animal Sciences, v. 36, n. 2, 2014, p. 201-208. https://doi.org/10.4025/actascianimsci.v36i2.22469

DE OLIVEIRA-MARTINS, ROSEANE-PINTO; ASSANTE-TORRES, RAFAEL; FERREIRA- SILVA, ANDRÉ; OLIVEIRA-FERREIRA, FRANKLYN; GUIMARÃES-CRUZ, FRANK-GEORGE; FERREIRA-RUFINO, JOÃOPAULO. Avaliação do perfil metabólico em diferentes fases do periparto de ovelhas Santa Inês na Amazônia Ocidental. Revista Brasileira de Saude e Producao Animal, v. 17, n. 1, 2016, p. 37-44. https://doi.org/10.1590/s1519-99402016000100004.

DUMONT, BERTRAND; GROOT, JEROEN; TICHIT, MURIEL. Make ruminants green again - how can sustainable intensification and agroecology converge for a better future?. Animal, v. 12, n. s2, 2018, p. s210-s219. https://doi.org/10.1017/S1751731118001350.

GARCIA, ANDREA E.; ABADIA, BEATRIZ; BARAHONA, ROLANDO; SANCHEZ, SOLANGE. Caracterización Fitoquímica de Factores Antinutricionales en Las Hojas de Uvito (Cordia dentata Poir). Revista MVZ Cordoba, v. 14, n. 1, 2009, p. 1611-1623. https://doi.org/10.21897/rmvz.370.

GEBREGIORGIS, FELEKE; TEGENE, NEGESSE; AJEBU, NURFETA. Feed intake and utilization in sheep fed graded levels of dried moringa (Moringa stenopetala) leaf as a supplement to Rhodes grass hay. Tropical Animal Health and Production, v. 44, n. 3, 2012, p. 511-517. https://doi.org/10.1007/s11250-011-9927-9.

GUYADER, JESSIE; JANZEN, HENRY; KROEBEL, ROLAND; BEAUCHEMIN, KAREN. Forage use to improve environmental sustainability of ruminant production. Journal of animal science, v. 94, n. 8, 2016, p. 3147-3158. https://doi.org/10.2527/jas.2015-0141

MANTILLA, CECILIA-LARA; OVIEDO-ZUMAQUÉ, LUÍS E.; BETANCUR-HURTADO, CESAR A. Efecto de la época de corte sobre la composición química y degradabilidad ruminal del pasto Dichanthium aristatum (Angleton). Revista Zootecnia Tropical. v. 28, 2010, p. 275-281

MARSETYO, MARSETYO; MUHAMMAD-ILYAS, MUMU; MUHAMAD, BASRI. The Effect of Various Legume Herbs Supplementation on Intake, Digestibility and Growth of Fat-tailed Lambs Given Mulato Grass. Animal Production, v. 21, n. 3, 2020, p. 129-135. https://doi.org/10.20884/1.jap.2019.21.3.784

MOYO, MEHLULI; RASHEED-ADEKUNLE, ADEBAYO; IGNATIUS-VERLA, NSAHLAI. Effects of diet and roughage quality, and period of the day on diurnal feeding behaviour patterns of sheep and goats under subtropical conditions. Asian-Australasian Journal of Animal Sciences, v. 32, n. 5, 2019, p. 675-690. https://doi.org/10.5713/ajas.17.0901.

UNITED STATES OF AMERICA. NATIONAL RESEARCH COUNCIL (NRC). Nutrient Requirements of Small Ruminants: sheep, goats, cervids and new world camelids. Washington (United States Of America): National Academies Press, 2007, 362 p. https://doi.org/10.17226/11654.

NIDERKORN, VINCENT; MARTIN, CÉCILE; BERNARD, MICKAËL; MORVAN, ALINE; ROCHETTE, YVANNE; BAUMONT, RENÉ. Effect of increasing the proportion of chicory in forage-based diets on intake and digestion by sheep. Animal, v. 13, n. 4, 2019, p. 718-726.

https://doi.org/10.1017/S1751731118002185 
ØRSKOV, EGIL-ROBERT; MCDONALD, IAN W. The estimation of protein degradability in the rumen from incubation measurements weighted according to rate of passage". The Journal of Agricultural Science, v. 92, n. 2, 1979, p. 499-503. https://doi.org/10.1017/S0021859600063048.

PATRA, AMLAN K.; YU, ZHONGTANG. Effects of vanillin, quillaja saponin, and essential oils on in vitro fermentation and protein-degrading microorganisms of the rumen. Applied Microbiology and Biotechnology, v. 98, n. 2, 2014, p. 897-905. https://doi.org/10.1007/s00253-013-4930-x

PATRA, AMLAN K.; YU, ZHONGTANG. Essential oils affect populations of some rumen bacteria in vitro as revealed by microarray (Rumen bact Array) analysis. Frontiers in Microbiology, v. 6, 2015, p. 297. https://doi.org/10.3389/fmicb.2015.00297.

PÉREZ-ALMARIO, NELSON; IBRAHIM, MOHAMMAD; VILLANUEVA, CRISTÓBAL; SKARPE, CHRISTINA; GUERIN, HUBERT. Diversidad forrajera tropical 1: Selección y uso de leñosas forrajeras en sistemas de alimentación ganadera para zonas secas de Nicaragua. Agroforestería en las Américas, v. 50, 2013, p. 37-43.

PÉREZ-ALMARIO, NELSON; IBRAHIM, MOHAMMAD; VILLANUEVA, CRISTÓBAL; SKARPE, CHRISTINA; GUERIN, HUBERT. Diversidad forrajera tropical 2. Rasgos funcionales que determinan la calidad nutricional y preferencia de leñosas forrajeras para su inclusión en sistemas de alimentación ganadera para zonas secas de Nicaragua. Agroforestería en las Américas, v. 50, 2013, p. 44-52.

SIO, STEFANUS; HILARIUS, YOSEP,SIKONE; USBOKO, CHARLES-ASAR. Nutrient digestion and body weight gain of Balinese cows getting basic ration of spear grass and rosewood leaves supplemented with falcata tree leaves". International Journal of Life Sciences (IJLS), v. 2, n. 2, 2018, p. 1-11. https://doi.org/10.29332/ijls.v2n2.114.

SNIFFEN, CHARLES J.; O'CONNOR, JIM D.; VAN SOEST, PETER J.; FOX, DANNY G.; RUSSELL, JIM. Net carbohydrate and protein system for evaluating cattle diets: II. Carbohydrate and protein availability. Journal of animal science, v. 70, n. 11. 1992, p. 3562-3577. https://doi.org/10.2527/1992.70113562x.

THOMPSON, WYATT; DEWBRE, JOE; PIERALLI, SIMONE; SCHROEDER, KATERYNA; PÉREZ-DOMÍNGUEZ, IGNACIO; WESTHOFF, PATRICK. Long-term crop productivity response and its interaction with cereal markets and energy prices. Food Policy, v. 84, 2019, p. 1-9. https://doi.org/10.1016/j.foodpol.2018.12.001.

TILLEY, J.M.A.; TERRY, R.A. A two? stage technique for the in vitro digestion of forage crops. Grass and Forage Science, v, 18, n. 2, 1963, p. 104-11. https://doi.org/10.1111/j.1365-2494.1963.tb00335.x.

UNITED STATES OF AMERICA. ASSOCIATION OF OFFICIAL AGRICULTURAL CHEMISTS (AOAC). Official Methods of Analysis of AOAC INTERNATIONAL. 20a ed. Gaithersburg (United States Of America): 2009.

VAN SOEST, PETER J.; ROBERTSON, JAMES B.; LEWIS, BETTY A. Methods for Dietary Fiber, Neutral Detergent Fiber, and Nonstarch Polysaccharides in Relation to Animal Nutrition. Journal of Dairy Science, v. 74, n. 10, 1991, p. 3583-3597. https://doi.org/10.3168/jds.S0022-0302(91)78551-2

VANDERMEULEN, SOPHIE; RAMÍREZ-RESTREPO, CARLOS-ALBERTO; BECKERS, YVES; HUGUES, CLAESSENS; BINDELLE, JÉRÔME. Agroforestry for ruminants: A review of trees and shrubs as fodder in silvopastoral temperate and tropical production systems. Animal Production Science CSIRO, v. 58, n. 5 , 2018, p. 767-777. https://doi.org/10.1071/AN16434.

VEGA-PÉREZ, CARLOS A.; GRAJALES-LOMBANA, HENRY A.; MONTOYA-RESTREPO, LUZ-ALEXANDRA. Sistemas de información: definiciones, usos y limitantes al caso de la producción ovina colombiana. Orinoquia, v. 21, n. 1, 2017, p.64-72. https://doi.org/10.22579/20112629.395

WEISS, WILLIAM. Predicting Energy Values of Feeds. Journal of Dairy Science, v. 76, n. 6, 1993, p. 1802-1811. https://doi.org/10.3168/jds.S0022-0302(93)77512-8. 